\title{
Study of TUBEX as a Rapid Diagnostic Test of Typhoid Fever
}

\author{
Gamal Saad El-Deeb ${ }^{1}$, Hosam El-Din Mostafa Seleem², \\ Gehan Abd El-Fatah Tawfeek ${ }^{3}$, Sameh Salah Emara ${ }^{4}$ \\ ${ }^{I}$ Tropical Medicine Department, Faculty of Medicine, Menoufia University, Egypt \\ ${ }^{2}$ Tropical Medicine Department, Faculty of Medicine, Menoufia University, Egypt \\ ${ }^{3}$ Clinical Pathology Department, Faculty of Medicine, Menoufia University ,Egypt \\ ${ }^{4}$ Shebin El-Kom Fever Hospital, Shebin El-Kom, Egypt
}

Corresponding Author Sameh Salah Emara

Mobile:

01067679331

E mail:

samegp@yahoo.com

Key words: Typhoid Fever, TUBEX test, Blood Culture, Widal test
Background and study aim : Several serologic tests for typhoid fever have been introduced which detect $\operatorname{IgM}$ or $\mathrm{IgG}$ antibodies to various purified antigens of S. Typhi as TUBEX test. This study aims to evaluate the performance of TUBEX test as a rapid diagnostic test of typhoid fever. Patients and Methods: The present study involved 44 patients admitted to Shebin El Kom Fever Hospital fulfilling the criteria of typhoid fever by WHO as (suffering from continuous fever at least 2 days, greater than $38.5^{\circ} \mathrm{C}$ in addition to headache, constipation or diarrhea) without identified cause of fever as pneumonia. Compared with 20 subjects; 10 with non specific fevers and 10 without fever using TUBEX

\section{INTRODUCTION}

In most cases, the cause of a febrile illness is a self limiting and presumed viral disease. However, 5-10\% of febrile illnesses have serious bacterial infections such as pneumonia, urinary tract infection, meningitis, bacteraemia or typhoid infection. These bacterial conditions can be difficult to distinguish from viral infections and benefit from early antibiotic therapy. The consequences of a delayed or missed diagnosis can be serious and, occasionally, fatal for the patient in the outbreak setting [1]. Typhoid fever remains an important cause of disease in developing countries. In 2010, it caused an estimated 408,837 episodes of illness in Africa [2]. The estimated incidence of typhoid fever in Egypt was 59/100,000 persons/year [3]. Salmonella typhi, the causative agent, is most frequently isolated from blood test in correlation to the usual Widal test and blood culture as a gold standard.

Results: We revealed sensitivity, specificity, positive predictive value and negative predictive value respectively for Widal; $75 \%, 60 \%, 80.5 \%, 52.2 \%$ and for culture; $65.9 \%, 100 \%, 100 \%, 57.1 \%$. In correlation with TUBEX test the results are at cutoff point 5 showing sensitivity, specificity, positive predictive value and negative predictive value respectively; $84.1 \%, 95 \%$, $97.4 \%$ and $73.1 \%$.

Conclusion: TUBEX results are superior to Widal test results in specificity and slightly in sensitivity as compared to the blood culture as a reference test.

during the first week of illness but can also be isolated during the second or third week of illness, during the first week of antimicrobial therapy and during clinical relapse [4]. Typhoid is transmitted by the fecal-oral route through ingestion of food and water contaminated by urine or feces from infected cases or carriers. The infection is rarely spread by casual contact. Shellfish (particularly oysters) taken from sewage-contaminated beds, raw fruits, vegetables fertilized by night soil (human excrement) and eaten raw, contaminated milk and milk products (usually contaminated by hands of carriers), are important sources of infection. Flies may also infect foods in which the organism can multiply to achieve an infective dose. The infective dose for typhoid is much lower than that of paratyphoid [5]. Recently, researchers have used mouse studies to find that a toxic protein complex 
produced by the bacterium (even in the absence of the microbe itself) causes most typhoid symptoms such as lethargy, stupor, and weight loss and leads to death [6]. Today most of the burden of typhoid fever occurs in the developing world, where sanitary conditions remain poor. Reliable data to estimate the burden of the disease in these areas are difficult to obtain, since many hospitals lack facilities for blood culture, and up to $90 \%$ of patients with typhoid are treated as outpatients. Community based studies have consistently shown higher levels of typhoid fever than public health figures suggest. The definitive diagnosis of typhoid fever requires the isolation of Salmonella enterica subspecies enterica serovar Typhi (S. Typhi) from the patient. Cultures of blood, stool, urine, rose spots, blood mononuclear cell-platelet fraction and bone marrow can all be useful for diagnosis [7]. Developing an inexpensive and rapid diagnostic test for typhoid fever that is both sensitive and specific has become a public health priority. Several serologic tests for typhoid fever have been introduced which detect IgM or IgG antibodies to various purified antigens of $S$. Typhi as TUBEX test. Studies evaluating TUBEX test revealed marked variation in its results [8].

\section{PATIENTS AND METHODS}

\section{Study area}

The present study was performed in El Menoufia governorate and all patients were admitted to Shebin El-Kom Fever Hospital.

\section{Time of the Study}

From December 2013 to October 2014.

They were chosen after taking written consent from out-patient clinic and in-patient department in Shebin El-Kom Fever Hospital.

The subjects are divided into two groups;

\section{Group 1 ( Patients )}

The present study involved 44 patients admitted to Shebin El-Kom Fever Hospital fulfilling the criteria of typhoid fever by WHO as (suffering from continuous fever at least 2 days, greater than $38.5^{\circ} \mathrm{C}$ in addition to headache, constipation or diarrhea) without identified cause of fever as pneumonia. The patients were 25 males and 19 females all are over 12 years old.

\section{Group 2 (Control)}

The control group was 20 subjects; 10 with non specific fevers and 10 without fever. They were
10 males and 10 females and all are over 12 years old.

\section{Procedure of the study}

All patients and control subjects were subjected to the following :

- Full and complete history with stress on fever, headach, abdominal pain, nausea, vomiting, diarrhea and constipation [9].

- Full clinical examination with stress on fever, rose spot, spleen and liver examination [9].

- Liver function tests including AST, ALT, ALP and Bilirubin [10].

- Complete blood picture [9].

- Widal agglutination test (Widal test is positive only in the second week of typhoid fever) [11].

- Blood culture [9].

- TUBEX TF.

\section{Sample collection}

Blood samples were collected from patients and controls, centrifuged and sera were stored at $20^{\circ} \mathrm{C}$.

\section{Statistical analysis}

The data collected were tabulated and analyzed by SPSS (statistical package for social science) version 22.0 on IBM compatible computer (IBM corp., New York, USA, 2012).

Two types of statistics were done

\section{Descriptive statistics [12]:}

e.g. percentage (\%), mean and standard deviation (SD).

\section{Analytic statistics [13]:}

- Chi-square test $\left(\chi^{2}\right)$ :

Was used to study association between two qualitative variables

- Fischer exact test:

For $2 \times 2$ tables when expected cell count of more than $25 \%$ of cases was less than 5 and p-value $<0.05$ was considered significant.

- Student t-test:

Is a test of significance used for comparison between two groups having quantitative variables.

- Mann-Whitney test (nonparametric test): Is a test of significance used for comparison between two groups not normally distributed having quantitative variables.

- Level of significance:

Was set as P-value $<0.05$. 


\section{RESULTS}

The patients were 25 male $(56.8 \%)$ and 19 females $(43.2 \%)$ their age range was $13-62$. The controls were 10 male $(50 \%)$ and 10 females (50\%), their age range was 13-60 (Table 1).

The symptoms were fever in 44 patients (100\%), headache in 18 patients $(40.9 \%)$, abdominal pain in 17 patients $(38.6 \%)$, rose spots in one patient (2.3\%), nausea and vomiting in 10 patients (22.7\%), diarrhea in 13 patients $(29.5 \%)$, constipation in 2 patients $(4.5 \%)$ and splenomegally in 28 patients $(63.6 \%)$ (Table 2).

Statistical analysis of results in cases when compared with controls revealed mild anaemia with mean $\mathrm{Hb}: 11.6 \pm 2.4 \mathrm{gm} \%$, mild leucopenia with W.B.C.s: $4.7 \pm 3$, neutropenia: $39.5 \pm 5.7 \%$, lymphocytosis : $58.2 \pm 5.6 \%$ and diminished platelet count : $222.7 \pm 118.3$ (Table 3).
Statistical analysis of the results revealed significant elevation of SGOT, SGPT and ALP with non significant bilirubin level. (Table 4)

Statistical analysis of the results revealed sensitivity, specificity, positive and negative predictive values respectively for Widal; $75 \%, 60 \%, 80.5 \%, 52.2 \%$ and for culture; $65.9 \%, 100 \%, 100 \%, 57.1 \%$ (Table 5).

Statistical analysis of TUBEX validity at cutoff point 5 showing sensitivity, specificity, positive (PPV) and negative predictive values (NPV) respectively; $84.1 \%, 95 \%, 97.4 \%$ and $73.1 \%$ (Table 6).

Statistical analysis of TUBEX test versus blood culture at cutoff point 5 revealed sensitivity; $100 \%$ specificity; $65.7 \%$, positive predictive value; $70.7 \%$ and negative predictive value; $100 \%$ (Table 7).

Table (1) : Demographic characteristics of studied groups

\begin{tabular}{|c|c|c|c|c|c|c|}
\hline & \multicolumn{2}{|c|}{$\begin{array}{c}\text { Cases group } \\
(\mathrm{no}=44)\end{array}$} & \multicolumn{2}{|c|}{$\begin{array}{c}\text { Control group } \\
(\mathrm{no}=\mathbf{2 0})\end{array}$} & $\begin{array}{c}\text { Mann-Whitney } \\
\text { Test }\end{array}$ & $P$ value \\
\hline $\begin{array}{l}\text { Age (years) } \\
\text { Mean } \pm \text { SD } \\
\text { Range }\end{array}$ & \multicolumn{2}{|c|}{$\begin{array}{c}36.6 \pm 14.3 \\
13-62\end{array}$} & \multicolumn{2}{|c|}{$\begin{array}{c}36.9 \pm 11.8 \\
13-60\end{array}$} & 0.18 & 0.86 \\
\hline & $\overline{\text { No }}$ & $\%$ & No & $\%$ & $\mathrm{X}^{2}$ test & P value \\
\hline $\begin{array}{l}\text { Gender } \\
\text { Male } \\
\text { Female }\end{array}$ & $\begin{array}{l}25 \\
19\end{array}$ & $\begin{array}{l}56.8 \\
43.2\end{array}$ & $\begin{array}{l}10 \\
10\end{array}$ & $\begin{array}{l}50 \\
50\end{array}$ & 0.26 & 0.61 \\
\hline
\end{tabular}


Table (2) : Comparison between studied groups regarding clinical manifestations

\begin{tabular}{|c|c|c|c|c|c|c|}
\hline & Cas & $\begin{array}{l}\text { sroup } \\
\text { 44) }\end{array}$ & Con & $\begin{array}{l}\text { group } \\
\text { 20) }\end{array}$ & Fisher's & P value \\
\hline & No & $\%$ & No & $\%$ & & \\
\hline $\begin{array}{r}\text { Fever } \\
\text { Yes } \\
\text { No }\end{array}$ & $\begin{array}{c}44 \\
0\end{array}$ & $\begin{array}{l}100 \\
0.0\end{array}$ & $\begin{array}{l}10 \\
10\end{array}$ & $\begin{array}{l}50 \\
50\end{array}$ & 27.75 & $<0.001^{* *}$ \\
\hline $\begin{array}{l}\text { Headache } \\
\text { Yes } \\
\text { No }\end{array}$ & $\begin{array}{l}18 \\
26\end{array}$ & $\begin{array}{l}40.9 \\
59.1\end{array}$ & $\begin{array}{c}0 \\
20\end{array}$ & $\begin{array}{c}0.0 \\
100\end{array}$ & 11.38\# & $0.001 *$ \\
\hline $\begin{array}{l}\text { Abdominal pain } \\
\text { Yes } \\
\text { No }\end{array}$ & $\begin{array}{l}17 \\
27 \\
\end{array}$ & $\begin{array}{l}38.6 \\
61.4\end{array}$ & $\begin{array}{c}0 \\
20 \\
\end{array}$ & $\begin{array}{c}0.0 \\
100\end{array}$ & $10.52 \#$ & $0.001 *$ \\
\hline $\begin{array}{l}\text { Rose spots } \\
\text { Yes } \\
\text { No }\end{array}$ & $\begin{array}{c}1 \\
43\end{array}$ & $\begin{array}{c}2.3 \\
97.7\end{array}$ & $\begin{array}{c}0 \\
20\end{array}$ & $\begin{array}{c}0.0 \\
100\end{array}$ & 0.76 & 0.38 \\
\hline $\begin{array}{l}\text { Nausea \& vomiting } \\
\text { Yes } \\
\text { No }\end{array}$ & $\begin{array}{l}10 \\
34\end{array}$ & $\begin{array}{l}22.7 \\
77.3\end{array}$ & $\begin{array}{c}0 \\
20\end{array}$ & $\begin{array}{c}0.0 \\
100\end{array}$ & 8.31 & $0.004 *$ \\
\hline $\begin{array}{l}\text { Diarrhea } \\
\text { Yes } \\
\text { No }\end{array}$ & $\begin{array}{l}13 \\
31\end{array}$ & $\begin{array}{l}29.5 \\
70.5\end{array}$ & $\begin{array}{c}0 \\
20\end{array}$ & $\begin{array}{c}0.0 \\
100\end{array}$ & 11.19 & $0.001 *$ \\
\hline $\begin{array}{l}\text { Constipation } \\
\text { Yes } \\
\text { No } \\
\end{array}$ & $\begin{array}{c}2 \\
42\end{array}$ & $\begin{array}{r}4.5 \\
95.5\end{array}$ & $\begin{array}{c}0 \\
20\end{array}$ & $\begin{array}{c}0.0 \\
100\end{array}$ & 1.53 & 0.22 \\
\hline $\begin{array}{l}\text { Splenomegaly } \\
\text { Yes } \\
\text { No }\end{array}$ & $\begin{array}{l}28 \\
16\end{array}$ & $\begin{array}{l}63.6 \\
36.4\end{array}$ & $\begin{array}{c}0 \\
20\end{array}$ & $\begin{array}{c}0.0 \\
100\end{array}$ & $22.63 \#$ & $<0.001 * *$ \\
\hline
\end{tabular}

\# $\mathrm{X}^{2}$ test $\quad$ *Significant difference $\quad * *$ Highly significant difference

Table (3) : Comparison between studied groups regarding CBC profiles

\begin{tabular}{|c|c|c|c|c|}
\hline & $\begin{array}{c}\text { Cases } \\
\text { group }(\text { no }=44)\end{array}$ & $\begin{array}{c}\text { Control group } \\
(\text { no= }=20)\end{array}$ & $\begin{array}{c}\text { t- } \\
\text { Test }\end{array}$ & P value \\
\hline $\begin{array}{l}\text { Hb }(\mathbf{g} / \mathbf{d l}) \\
\text { Mean } \pm \text { SD } \\
\text { Range } \\
\end{array}$ & $\begin{array}{c}11.6 \pm 2.4 \\
8-16 \\
\end{array}$ & $\begin{array}{c}11.9 \pm 1.7 \\
9-15 \\
\end{array}$ & 0.37 & 0.71 \\
\hline $\begin{array}{l}\text { WBC }(\text { cell } / \mathbf{m c l}) \times \mathbf{1 0}^{3} \\
\text { Mean } \pm \text { SD } \\
\text { Range }\end{array}$ & $\begin{array}{c}4.7 \pm 3.0 \\
2.2-14\end{array}$ & $\begin{array}{c}6.1 \pm 1.4 \\
4-10\end{array}$ & 3.94\# & $<0.001 * *$ \\
\hline $\begin{array}{l}\text { Platelets }(\text { cell } / \mathbf{m c l}) \times \mathbf{1 0}^{3} \\
\text { Mean } \pm \text { SD } \\
\text { Range }\end{array}$ & $\begin{array}{c}222.7 \pm 118.3 \\
100-470\end{array}$ & $\begin{array}{c}303.3 \pm 81.4 \\
145-425\end{array}$ & $2.79 \#$ & $0.005^{*}$ \\
\hline $\begin{array}{l}\text { Neutrophils (\%) } \\
\text { Mean } \pm \text { SD } \\
\text { Range }\end{array}$ & $\begin{array}{c}39.5 \pm 5.7 \\
31-49\end{array}$ & $\begin{array}{c}62.1 \pm 9.8 \\
45-80 \\
\end{array}$ & 11.68 & $<0.001 * *$ \\
\hline $\begin{array}{l}\text { Lymphocytes (\%) } \\
\text { Mean } \pm \text { SD } \\
\text { Range }\end{array}$ & $\begin{array}{c}58.2 \pm 5.6 \\
49-67 \\
\end{array}$ & $\begin{array}{c}35.3 \pm 9.4 \\
19-53 \\
\end{array}$ & 12.12 & $<0.001 * *$ \\
\hline
\end{tabular}

\# Mann-Whitney test

Normal ranges

$\mathrm{Hb} \quad$ Male

*Significant difference

**Highly significant difference

WBCs

Female $\quad 12.3-15.3 \mathrm{~g} / \mathrm{dl}$

Platelet

$4-11 \mathrm{cell} / \mathrm{mcl}$ (microliter)

Neutrophil

$150-450 \mathrm{cell} / \mathrm{mcl}$

Lymphocyte

$40-80 \%$

$20-40 \%$

El-Deeb et al., Afro-Egypt J Infect Endem Dis 2015; 5(2): 62-68

http//:mis.zu.edu.eg/ajied/home.aspx 
Table (4) : Comparison between studied groups regarding liver functions

\begin{tabular}{|l|c|c|c|c|}
\hline \multicolumn{1}{|c|}{} & $\begin{array}{c}\text { Cases } \\
\text { group }(\mathbf{n o = 4 4})\end{array}$ & $\begin{array}{c}\text { Control group } \\
(\mathbf{n o = 2 0})\end{array}$ & $\begin{array}{c}\text { t- } \\
\text { Test }\end{array}$ & P value \\
\hline $\begin{array}{c}\text { SGOT (IU/L) } \\
\text { Mean } \pm \text { SD } \\
\text { Range }\end{array}$ & $\begin{array}{c}48.8 \pm 7.4 \\
35-55\end{array}$ & $\begin{array}{c}18.9 \pm 6.5 \\
10-33\end{array}$ & 15.42 & $<0.001^{* *}$ \\
\hline $\begin{array}{c}\text { SGPT (IU/L) } \\
\text { Mean } \pm \text { SD } \\
\text { Range }\end{array}$ & $\begin{array}{c}55.1 \pm 7.8 \\
40-60\end{array}$ & $\begin{array}{c}22.3 \pm 9.7 \\
10-50\end{array}$ & 13.36 & $<0.001^{* *}$ \\
\hline $\begin{array}{l}\text { ALP(IU/L) } \\
\text { Mean } \pm \text { SD } \\
\text { Range }\end{array}$ & $\begin{array}{c}188.4 \pm 148.01 \\
30-650\end{array}$ & $\begin{array}{c}57.5 \pm 21.4 \\
25-90\end{array}$ & $4.41 \#$ & $<0.001 * *$ \\
\hline $\begin{array}{l}\text { Bilirubin (mg/dl) } \\
\text { Mean } \pm \text { SD } \\
\text { Range }\end{array}$ & $\begin{array}{c}0.97 \pm 0.19 \\
0.5-1.3\end{array}$ & $\begin{array}{c}1.01 \pm 0.16 \\
0.7-1.3\end{array}$ & 0.96 & 0.34 \\
\hline
\end{tabular}

\# Mann-Whitney test

Normal ranges :

SGOT 5-40 IU/L

**Highly significant difference

ALP 25-100 IU/L

SGPT 7-60 IU/L

Bilirubin $0.2-1.5 \mathrm{mg} / \mathrm{dl}$

Table (5) : Validity of Widal test and blood culture in diagnosis of typhoid fever

\begin{tabular}{|l|c|c|c|c|c|}
\hline & Sensitivity & Specificity & PPV & NPV & Accuracy \\
\hline Widal test & $75 \%$ & $60 \%$ & $80.5 \%$ & $52.2 \%$ & $70.3 \%$ \\
\hline Blood culture & $65.9 \%$ & $100 \%$ & $100 \%$ & $57.1 \%$ & $76.6 \%$ \\
\hline
\end{tabular}

Table (6) : Validity of TUBEX test in diagnosis of typhoid fever

\begin{tabular}{|c|c|c|c|c|c|c|c|}
\hline & AUC & Cutoff point & Sensitivity & Specificity & PPV & NPV & Accuracy \\
\hline TUBEX & 0.95 & 5 & $84.1 \%$ & $95 \%$ & $97.4 \%$ & $73.1 \%$ & $87.5 \%$ \\
\hline
\end{tabular}

AUC-- Area Under the Curve

Table (7) : Evaluation of TUBEX test versus blood culture in diagnosis of typhoid fever

\begin{tabular}{|l|c|c|c|c|c|c|c|}
\hline & AUC & Cutoff point & Sensitivity & Specificity & PPV & NPV & Accuracy \\
\hline TUBEX & 0.95 & 5 & $100 \%$ & $65.7 \%$ & $70.7 \%$ & $100 \%$ & $81.3 \%$ \\
\hline
\end{tabular}

AUC-- Area Under the Curve

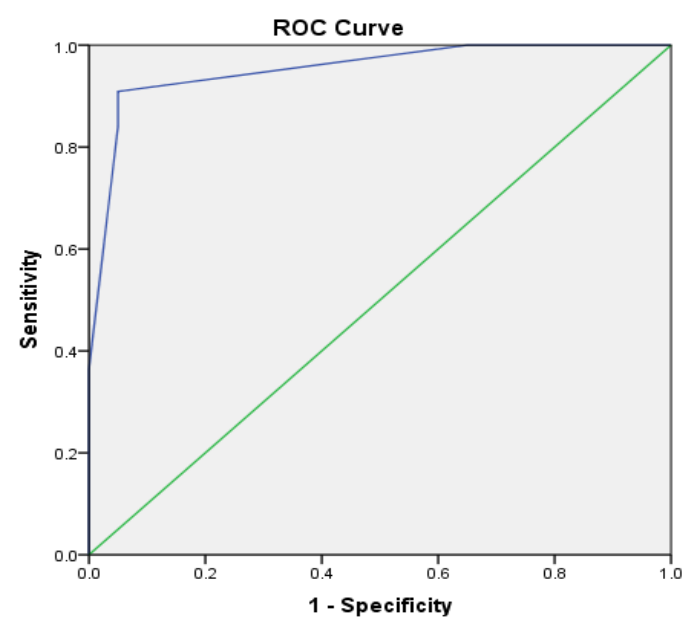

Diagonal segments are produced by ties.

Fig (1) : Receiver operator characteristic curve showing the relation between sensitivity and specificity at different cut-off points for TUBEX test 


\section{DISCUSSION}

The present study was stressed on the newly emerged rapid antibody test Tubex TF who show simplicity in the procedure, difficulty in interpretation of the results as it is a colorimetric test and some difference in the time of reading of the results which significantly prolonged (30-60 minutes) more than that provided in the pamphlet and closely similar results of sensitivity; $84.1 \%$, specificity, 95\%, PPV; $97.4 \%$ and NPV; $73.1 \%$. These results agreed with the following studies:

Ley et al. [14] found that Tubex has a sensitivity of $79 \%$ and a specificity of $89-97 \%$ irrespective of control group. The Multi-Test dipstick was the most costly assay, presumably because the dipstick measures antibodies to five different pathogens. Although the TUBEX was the simplest. A limitation of the TUBEX test, which uses a colorimetric reaction, is the potential for difficulty in interpreting the results of hemolyzed samples. Another concern is that the TUBEX may produce a false positive result in persons with recent $S$. enterica serotype enteritidis infection and result in inappropriate antibiotic treatment [15].

Dutta et al. [16] stated that past studies have shown that the use of TUBEX-TF yield highly variable sensitivity and specificity profiles, depending on the country and/or geographical region, study population, and nature of the study. Bangladesh 60\% \& 85\%, Vietnam 79\% \& 89\%, Poland 93\% \& 95\% and Philippines 95\% \& $80 \%$. This has created difficulties in comparing results between studies and setting worldwide standards for typhoid fever diagnosis. The specificity of TUBEX was extremely good $(100 \%)$. This finding is not surprising, since previous investigators found $S$. typhi LPS to be very specific [17]. Narrowing this antigen to the immunodominant O9 determinant would, in theory, increase the specificity of the assay. Indeed, using an inhibition ELISA to measure anti-O9 antibodies in patients, we observed very good specificity with the test previously. The a-D-Tyvelose is the immunodominant sugar of the $\mathrm{O} 9$ determinant. An extremely rare sugar in nature, a-D tyvelose is antigenically different from the b-D-tyvelose found in T. Spiralis or the L-tyvelose in Ascaris lumbricoides [18]. However, the $\mathrm{O} 9$ determinant is present not only in S. typhi but also in several other serotypes of Salmonella (serogroup D) such as $S$. enteritidis and $S$. sendai. However, many of these bacteria are not invasive and may not stimulate a systemic antibody response. The extent to which TUBEX detects infection caused by these salmonellae or the paratyphoid serotypes remains to be investigated [18]. Previously, using the ELISA equivalent of TUBEX we found that serum samples from septicemic patients infected with Salmonella organisms not belonging to serogroup D (one with $S$. choleraesuis, one with $S$. johannesburg, and one with $S$. senftenberg) were negative in the test, whereas that from a patient infected systemically with $S$. sendai (serogroup D) was weakly positive. Interestingly, serum samples from two patients infected with $S$. paratyphi $A$, a non-serogroup D organism, were strongly positive in the test. The reactivity was due to the presence in the patients of anti-O12 antibodies, which bound to the $\mathrm{O} 12$ determinant in the detecting antigen (LPS) and consequently blocked, by steric hindrance, the binding of the reagent $\mathrm{mAb}$ to the adjoining $\mathrm{O} 9$ determinant in the LPS [19]. Consequently, TUBEX will potentially give positive results for infections caused by any invasive Salmonella bacteria which bear the $\mathrm{O} 9$ or $\mathrm{O} 12$ antigen. Thus, to make TUBEX more specific for typhoid fever, supplementary tests such as those detecting anti- $\mathrm{Vi}$, anti- $\mathrm{dH}$, or anti-OM antibodies, can be included [19].

\section{CONCLUSION}

As typhoid fever remains an important cause of disease in developing countries, Widal test still have debating results while the gold standard blood culture for Salmonella typhi in most of the developing world, where widespread antibiotic availability and prescribing are reasons for low sensitivity of blood cultures. On the other hand we found TUBEX results superior to Widal test results in specificity and slightly in sensitivity with closely related specificity to blood culture which is promising as a rapid test.

\section{Funding: None. \\ Conflicts of interest: None. \\ Ethical approval: Approved}

\section{REFERENCES}

1. Kawano, RL, Leano, SA. , Agdamag, DM. Comparison of serological test kits for diagnosis of typhoid fever in the Philippines. $J$ Clin Microbiol 2013 ; 45: 246-247.

2. Baker S, Favorov M, Dougan G. Searching for the elusive typhoid diagnostic. BMC Infect Dis. 2010 Mar 5;10:45. 
3. Srikantiah P, Girgis FY, Luby SP, Jennings G, Wasfy MO, Crump JA, Hoekstra RM, Anwer M, Mahoney FJ. Population-based surveillance of typhoid fever in Egypt. Am J Trop Med Hyg. 2006 Jan;74(1):114-9

4. Merrell DS, Falkow S. Frontal and stealth attack strategies in microbial pathogenesis. Nature 2004 Jul 8;430(6996):250-6.

5. Heymann DL. Control of Communicable Disease Manual. An offical report of the American Public Health Association. American Public Health Association 2008: 978-0.

6. Song J, Gao X, Galán JE. Structure and function of the Salmonella Typhi chimaeric A(2)B(5) typhoid toxin. Nature 2013 Jul 18;499(7458):350-4.

7. Bhutta ZA. Current concepts in the diagnosis and treatment of typhoid fever. BMJ. $2006 \mathrm{Jul}$ 8;333(7558):78-82.

8. Rahman M, Siddique AK, Tam FC, Sharmin S, Rashid H, Iqbal A et al. Rapid detection of early typhoid fever in endemic community children by the TUBEX O9-antibody test. Diagn Microbiol Infect Dis. 2007 Jul;58(3):275-81.

9. Gilman RH, Terminel M, Levine MM, Hernandez-Mendoza P, Hornick RB. Relativeefficacy of blood, urine, rectal swab, bone-marrow, and rose-spot ultures forrecovery of Salmonella typhi in typhoid fever.Lancet. 1975 May31;1(7918):1211-3.

10. Gella FJ, Olivella T, Cruz Pastor M, Arenas J, Moreno R, Durban R, Gomez JA. A simple procedure for the routine determination of aspartate aminotransferase and alanine aminotransferase with pyridoxal phosphate. Clin Chim Acta. 1985 Dec31;153(3):241-7.

11. Freter R. Prospects for preventing the association of harmful bacteria with host mucosal surfaces. In Bacterial adherence, pp. 439-458. Springer Netherlands, 1980.

12. Plackett RL. Karl Pearson and the Chi-Squared Test. International Statistical Review. International Statistical Institute (ISI) $1983 ; 51$ (1):59-72.
13. Corder GW, Foreman DI. Nonparametric statistics for non-statisticians: a step-by-step approach. John Wiley \& Sons, 2009.

14. Ley B, Thriemer K, Ame SM, Mtove GM, von Seidlein L, Amos B et al. Assessment and comparative analysis of a rapid diagnostic test (Tubex ${ }^{\circledR)}$ )for the diagnosis of typhoid fever among hospitalized children in rural Tanzania.BMC Infect Dis. 2011 May 24;11:147.

15. Oracz G, Feleszko W, Golicka D, Maksymiuk J, Klonowska A, Szajewska H. Rapiddiagnosis of acute Salmonella gastrointestinal infection. Clin Infect Dis. 2003Jan 1;36(1):112-5.

16. Dutta S, Sur D, Manna B, Sen B, Deb AK, Deen JL et al.Evaluation of new-generatio serologic tests for the diagnosis of typhoid fever: data from a community-based surveillance in Calcutta, India. Diagn Microbiol Infect Dis. 2006 Dec;56(4):359-65.

17. Shaheen HI, Girgis NI, Rodier GR, Kamal KA. Evaluation of the response of human humoral antibodies to Salmonella typhi lipopolysaccharide in an area of endemic typhoid fever. Clin Infect Dis. 1995 Oct;21(4):1012-3.

18. Lim PL, Tam FC, Cheong YM, Jegathesan M. One-step 2-minute test to detect typhoid-specific antibodies based on particle separation in tubes. $J$ Clin Microbiol. 1998 Aug;36(8):2271-8.

19. Lim PL, Ho MY. Diagnosis of enteric fever by inhibition assay using peroxidase-labelled monoclonal antibody and Salmonella typhi lipopolysaccharide. Aust J Exp Biol Med Sci. 1983 Dec;61 ( Pt 6):687-704.

Peer reviewer: Tarik Zaher ,Professor of Tropical Medicine and Hepatogastroenterology, Faculty of Medicine, Zagazig University, Egypt.

Editor: Ehab Darwish, Lecturer of Tropical Medicine and Hepatogastroenterology, Faculty of Medicine, Zagazig University, Egypt 